\title{
JIMUPB

\section{ANALYSIS OF THE IMPACT OF LEADERSHIP STYLE AND ORGANIZATIONAL CULTURE ON EMPLOYEE PERFORMANCE THROUGH ORGANIZATIONAL CITIZENSHIP BEHAVIOR AS AN INTERVENING VARIABLES MODERATED WORK MOTIVATION IN GRIYA MAHARDHIKA GENERAL HOSPITAL YOGYAKARTA}

\author{
By \\ Revisan Prisintava Hia ${ }^{1}$, Gendro Wiyono ${ }^{2}$, Kusuma Chandra Kirana ${ }^{3}$ \\ Master of Management Study Program, Sarjanawiyata Tamansiswa University \\ *Email: revisanprisintava23@gmail.com
}

\begin{abstract}
This research was conducted to analyze the impact of leadership style and organizational culture on employee performance through organizational citizenship behavior as an interverning variable moderated by work motivation. The data collection method used in this research was a census technique using a Likert scale. The instrument test in this study used the IBM SPSS Statistics 26 software with the value of the validity and reliability of the $r$ table sought at a significance of 0.05 with a 2 -tailed. Inferential analysis and path analysis in this study used Partial Least Square (PLS) analysis tools, namely variance-based SEM with SmartPLS 3 software. The results showed that hypothesis 1 was accepted, hypothesis 2 was accepted, hypothesis 3 was accepted, hypothesis 4 was rejected, hypothesis 5 was accepted, hypothesis 6 was accepted.
\end{abstract}

Keywords: Leadership Style, Organizational Culture, Organizational Citizenship Behavior, Employee Performance, Work Motivation

\section{INTRODUCTION}

Companies seeking competitive advantage through employees must be able to manage the behavior and outcomes of all employees. Traditionally, the formal performance appraisal system was seen as the primary means of managing employee performance. Performance appraisal is an administrative task carried out by managers, and is the main responsibility of the human resources (HR) department. Likewise, Griya Mahardhika General Hospital Yogyakarta, to be able to achieve the company's targets, of course, requires the ability of a manager who is able to manage employee performance in terms of serving.

To achieve the success of health services in hospitals can not be separated from the various factors of nursing services. Therefore, in order to continue to develop the quality of health services and for the survival of the organization, hospital management needs to improve employee performance. In this case, the expected increase in employee performance is to be able to improve their performance as much as possible to provide satisfactory service. 
Employees who can be managed well can be assessed through the performance of their employees. Performance is the result of work achieved by someone based on job requirements. In addition, employee performance is influenced by several factors, such as salary, work environment, organizational culture, leadership, work motivation, work discipline, job satisfaction, and work communication (Maswar et al., 2020). To be able to achieve maximum performance, there are several things that are determining factors in this study, including: leadership style, organizational culture, Organizational Citizenship Behavior (OCB), and work motivation.

Based on the results of the pre-survey conducted at the Griya Mahardhika General Hospital Yogyakarta, it shows that the leadership style used is the directive leadership style. According to Saskia \& Arief (2020) which refers to Thoha's opinion that directive leadership is leadership in which all pattern-making and decision-making are in the hands of the leader. The subordinates feel they have a responsibility so they know exactly what their duties are and the leader gives specific directions to their subordinates. This is in accordance with the statement from the Director of General and Finance of the Griya Mahardhika General Hospital that all decisions and orders are in the hands of the leadership. This statement was also confirmed by the head of general and human resources. This is because all activities at the Griya Mahardhika General Hospital Yogyakarta produce outputs in the form of crucial services if they are not carried out based on direct orders from the leadership, this will certainly have an impact on employee performance results. As for the directive leadership style, the organizational culture at Griya Mahardhika General Hospital Yogyakarta tends not to provide space for employees to take the initiative in work, because it is feared that it will not be in accordance with procedures and will have bad consequences, which will also have an impact on employee performance results. According to Maria (2018)The virtue of organizational culture is control and direction in shaping human attitudes and behaviors that involve themselves in an organizational activity. Individually or in groups, a person will not be separated from the organizational culture and in general they will be influenced by the diversity of existing resources as a stimulus for someone to act.

Employees at Griya Mahardhika General Hospital Yogyakarta have extra role behavior, namely being willing to do the work given by their superiors outside of the job desk and helping each other between employees to achieve organizational goals. Mutual assistance referred to at Griya Mahardhika Hospital Yogyakarta is for example when there is work that can be continued but has not been completed because it requires a certain time span in completing the task, the employee at the next working hour is willing to continue the task. As for other examples in terms of mutual assistance at Griya Mahardhika General Hospital Yogyakarta, for example when one division has completed all its duties during its working hours but the working hours are still not finished, then the employee is willing to help employees in other divisions. According to Natalie (2019) Organizational Citizenship Behavior shows behavior that is not explicitly stated in an employee's job description but is behavior that should be shown by employees as part of the organization. This OCB behavior is not an employee's obligation as stated in their main duties and functions, but is a behavior that employees voluntarily or sincerely do. Employees don't expect rewards when they volunteer to help their co-workers.

In addition to leadership style, organizational culture, and OCB, another factor that affects employee performance at Griya Mahardhika General Hospital Yogyakarta is work motivation. As for the work motivation for the employees of the Griya Mahardhika General Hospital Yogyakarta is the appreciation of the work performance carried out by each employee in the form of additional salary benefits which are assessed every month. In addition to rewards, there are also penalties for employees who violate company rules. Examples of punishments that employees get at Griya Mahardhika General Hospital Yogyakarta are when employees are late for work 2-30 minutes, working hours are added 2 hours than they should be, if the delay 
is more than 30 minutes then the day will be considered absent, this will have an impact on the payroll employees will receive in that month.

This research will be conducted by taking samples of medical and non-medical personnel at Griya Mahardhika General Hospital Yogyakarta. The selection of objects for medical and non-medical personnel in hospitals is very relevant because as a company engaged in the service industry, the role of human resources is a very significant factor in assessing employee performance. To produce output in the form of employee performance in accordance with the goals of the company, the role of the leader is very important in creating a conducive working atmosphere and supported by a positive organizational culture in terms of being oriented to company goals and oriented to employees. So that employees can show the characteristics of organizational citizenship behavior, for example helping selflessly, voluntary, participation and support for organizational functions, polite behavior, doing good and alleviating problems faced by co-workers and emphasizing positive aspects of company this will be work motivation for employees.

Based on this thought, the researcher is interested in conducting a research entitled "Analysis of the Impact of Leadership Style and Organizational Culture on Employee Performance Through Organizational Citizenship Behavior as an Intervening Variable Moderated by Work Motivation at Griya Mahardhika General Hospital Yogyakarta".

\section{METHODS}

This research was conducted in April 2021 at Griya Mahardhika General Hospital Yogyakarta. The subjects of this research were employees at the Griya Mahardhika General Hospital Yogyakarta. The population in this research were all employees at the Griya Mahardhika General Hospital Yogyakarta, amounting to 116 people. The method used to determine the sample size is the Slovin method. The number of samples used for this research was 90 people. Samples were taken using a probability model sampling technique, and the method of determining the sample was simple random sampling. The variables used in this study are leadership style (X1) and organizational culture (X2) as independent variables, organizational citizenship behavior (Y1) as intervening variable, employee performance (Y2) as dependent variable, and work motivation $(Z)$ as a moderating variable. The data collection method used in this research was a census technique using a Likert scale. The instrument test in this study used the IBM SPSS Statistics 26 software with the value of the validity and reliability of the $r$ table sought at a significance of 0.05 with a 2-tailed. Inferential analysis and path analysis in this research use Partial Least Square (PLS) analysis tools, namely variancebased SEM with SmartPLS 3 software.

\section{RESULT AND DISCUSSION}

Based on the research framework that has been carried out indicator tests using smartPLS as shown in Figure 1 below: 


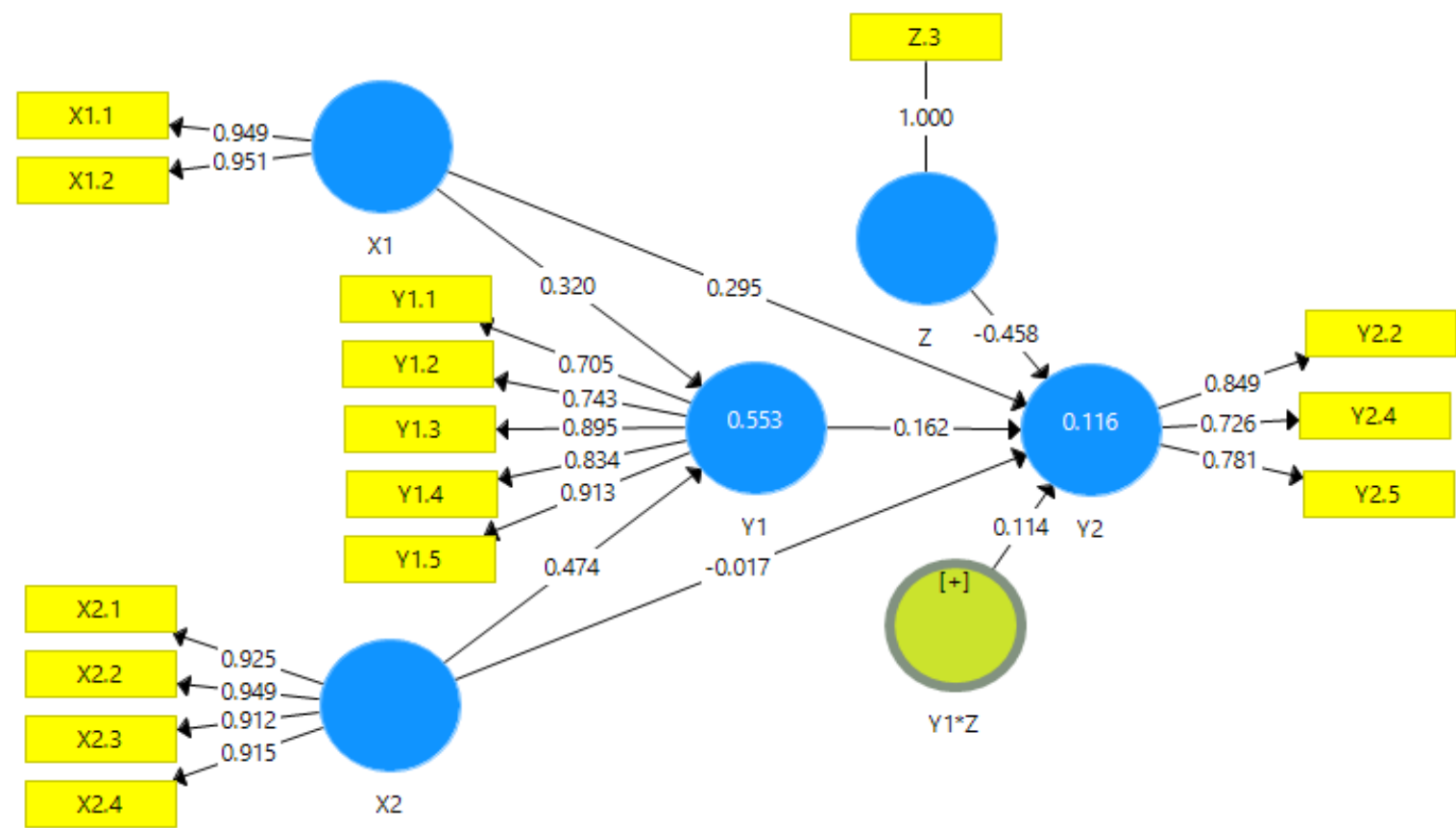

\section{Figure 1: Research Framework Model After Testing Indicators Using SmartPLS}

Then the results obtained from this research can be seen through hypothesis testing, intervening analysis and moderating analysis. To test the hypothesis is described in table 1, as follows:

Table 1: Hypothesis Test

\begin{tabular}{|l|c|c|}
\hline \multicolumn{1}{|c|}{ HYPOTHESIS } & $\begin{array}{c}\text { ORIGINAL SAMPLE } \\
\text { (parameter } \\
\text { coefficient) }\end{array}$ & STATUS \\
\hline $\begin{array}{l}\text { Leadership style has a positive } \\
\text { effect on organizational } \\
\text { citizenship behavior }\end{array}$ & 0.320 & $\begin{array}{c}\text { Positive } \\
\text { (Hypothesis } \\
\text { accepted) }\end{array}$ \\
\hline $\begin{array}{l}\text { Organizational culture has a } \\
\text { positive effect on organizational } \\
\text { citizenship behavior }\end{array}$ & $\begin{array}{c}\text { Positive } \\
\text { (Hypothesis } \\
\text { accepted) }\end{array}$ \\
\hline $\begin{array}{l}\text { Leadership style has a positive } \\
\text { effect on employee performance }\end{array}$ & 0.295 & $\begin{array}{c}\text { Positive } \\
\text { (Hypothesis } \\
\text { accepted) }\end{array}$ \\
\hline $\begin{array}{l}\text { Organizational culture has a } \\
\text { positive effect on employee } \\
\text { performance }\end{array}$ & -0.017 & $\begin{array}{c}\text { Negative } \\
\text { (Hypothesis } \\
\text { rejected) }\end{array}$ \\
\hline $\begin{array}{l}\text { Organizational Citizenship } \\
\text { Behavior positive effect on } \\
\text { employee performance }\end{array}$ & 0.162 & $\begin{array}{c}\text { Positive } \\
\text { (Hypothesis } \\
\text { accepted) }\end{array}$ \\
\hline $\begin{array}{l}\text { Work motivation can moderate } \\
\text { the relationship between } \\
\text { organizational citizenship } \\
\text { behavior and employee } \\
\text { performance }\end{array}$ & 0.114 & $\begin{array}{c}\text { Positive } \\
\text { (Hypothesis } \\
\text { accepted) }\end{array}$ \\
\hline
\end{tabular}


Based on table 1, regarding hypothesis testing for the first hypothesis, it shows that there is a positive influence between leadership style on organizational citizenship behavior with the original sample value of 0.320 . Based on the results of the questionnaire, it shows that the highest percentage of answers is agree $(65 \%)$ to the leadership style that exists at Griya Mahardhika General Hospital Yogyakarta. This proves that as many as $65 \%$ of employees agree with the leadership style at Griya Mahardhika General Hospital Yogyakarta, so that it has a positive effect on organizational citizenship behavior with an original sample value of 0.320 . Which means that the better the leadership style applied, the more organizational citizenship behavior will be on every employee of the Griya Mahardhika General Hospital Yogyakarta,

The second hypothesis shows that there is a positive influence between organizational culture on organizational citizenship behavior with the original sample value of 0.474 . Based on the results of the questionnaire, it shows that the highest percentage of answers is agree $(60 \%)$ to the organizational culture that exists at Griya Mahardhika General Hospital Yogyakarta. This proves that $60 \%$ of employees agree with the organizational culture at Griya Mahardhika General Hospital Yogyakarta, so that it has a positive effect on organizational citizenship behavior with an original sample value of 0.474 . Which means that the better the organizational culture that is applied, the more organizational citizenship behavior will be on every employee of the Griya Mahardhika General Hospital Yogyakarta, so the hypothesis is accepted.

The third hypothesis shows that there is a positive influence between leadership style on employee performance with the original sample value of 0.295 . Based on the results of the questionnaire, it shows that the highest percentage of answers is agree $(65 \%)$ to the leadership style at Griya Mahardhika General Hospital Yogyakarta. This proves that as many as $65 \%$ of employees agree with the leadership style at Griya Mahardhika General Hospital Yogyakarta, so that it has a positive effect on employee performance with an original sample value of 0.295. Which means that the better the leadership style applied, the more the performance of employees at Griya Mahardhika General Hospital Yogyakarta, so the hypothesis is accepted.

The fourth hypothesis shows that there is a negative influence between organizational culture on employee performance with the original sample value of -0.017 . Based on the results of the questionnaire, it shows that the highest percentage of answers is agree $(60 \%)$ to the organizational culture that exists at Griya Mahardhika General Hospital Yogyakarta. Although as many as $65 \%$ of employees agree with the organizational culture applied at Griya Mahardhika General Hospital Yogyakarta, the original sample value of the relationship between organizational culture and employee performance is a minus sign, namely -0.017 . Which means that organizational culture at Griya Mahardhika General Hospital Yogyakarta cannot affect employee performance, so the hypothesis is rejected.

The fifth hypothesis shows that there is a positive influence between organizational citizenship behavior on employee performance with the original sample value of 0.162 . Based on the results of the questionnaire, it shows that the highest percentage of answers is agree $(66 \%)$ on organizational citizenship behavior at Griya Mahardhika General Hospital Yogyakarta. This proves that as many as $66 \%$ of employees already have extra role behavior while working, so that it has a positive effect on employee performance with an original sample value of 0.162 . Which means that the more employees who apply organizational citizenship behavior at work, the more the performance of employees at Griya Mahardhika General Hospital Yogyakarta will increase, so the hypothesis is accepted.

The sixth hypothesis shows that work motivation can moderate the relationship between organizational citizenship behavior and employee performance, with the original sample value of 0.114. Based on the results of the questionnaire, it shows that the statement item on the work motivation variable with the indicator of the need for achievement is the indicator with the 
highest percentage of answers, this proves that the need for achievement can be a work motivation that can moderate the relationship between organizational citizenship behavior and employee performance. Which means that the higher the employee's work motivation, the stronger the relationship between organizational citizenship behavior and employee performance.

The intervening analysis and moderation analysis are described in Tables 2 and 3, as follows:

Table 3: Intervening Analysis

\begin{tabular}{|c|c|c|c|c|c|c|c|}
\hline \multirow{3}{*}{$\begin{array}{l}\text { Endogenous } \\
\text { Eunction } \\
\text { Function }\end{array}$} & \multicolumn{3}{|c|}{$\begin{array}{l}\text { Direct Effects (Path } \\
\text { Coefficients) }\end{array}$} & \multicolumn{2}{|c|}{ Indirect Effect } & \multicolumn{2}{|c|}{ Total Effects } \\
\hline & \multicolumn{7}{|c|}{ Employee Performance (Y2) } \\
\hline & & Coef. & $\mathrm{P}_{\text {value }}$ & Coef. & $\mathrm{P}_{\text {value }}$ & Coef. & $\mathrm{P}_{\text {value }}$ \\
\hline Leadership Style & $\mathrm{X} 1$ & 0.295 & 0.239 & 0.052 & 0.497 & 0.347 & 0.146 \\
\hline Organizational culture & $\mathrm{X} 2$ & -0.017 & 0.936 & 0.077 & 0.448 & 0.060 & 0.800 \\
\hline
\end{tabular}

*) Organizational Citizenship Behavior (intervening variable)

Table 4: Moderation Analysis

\begin{tabular}{|l|c|c|c|}
\hline \multirow{2}{*}{ Endogenous Function } & \multicolumn{3}{|c|}{ Path Coefficients } \\
\cline { 2 - 4 } & \multicolumn{3}{|c|}{ Employee Performance (Y2) } \\
\cline { 2 - 4 } $\begin{array}{l}\text { Exogenous } \\
\text { Function }\end{array}$ & & Coef. & P value $^{*}$ \\
\hline $\begin{array}{l}\text { Organizational Citizenship } \\
\text { Behavior }\end{array}$ & $\mathrm{Y} 1$ & 0.114 & 0.103 \\
\hline Work Motivation (Exogenous) & $\mathrm{Z}$ & -0.458 & 0.094 \\
\hline
\end{tabular}

*) Work Motivation (Moderating Variable)

Based on the results of the analysis of the intervening variables shown in table 2 , it shows that the leadership style variable on employee performance has a direct effects coefficient value of 0.295 with a $\mathrm{P}_{\text {value }}$ of 0.239 , which means that the direct effect of the leadership style variable has a direct positive effect on employee performance but is not significant, because $\mathrm{P}_{\text {value }} 0.239$ $>0.05$. In the indirect effect, leadership style has a coefficient value of 0.052 with a $\mathrm{P}_{\text {value }}$ of 0.497 , which means that leadership style has a positive effect through organizational citizenship behavior as an intervening variable on employee performance but is not significant, because the $\mathrm{P}_{\text {value }}$ is $0.497>0.05$. And in total leadership style has a positive effect on employee performance with a value of 0.347 but not significant because $\mathrm{P}_{\text {value }} 0,146>0,05$.

The organizational culture variable on employee performance has a direct effect coefficient of -0.017 with a $\mathrm{P}_{\text {value }}$ of 0.936 , which means that the direct effect of the organizational culture variable does not directly affect employee performance and is also not significant, because the $\mathrm{P}_{\text {value }}$ is $0.936>0.05$. In the indirect effect, organizational culture has a coefficient value of 0.077 with a $\mathrm{P}_{\text {value }}$ of 0.448 , which means that organizational culture has a positive effect through organizational citizenship behavior as an intervening variable on employee performance but is not significant, because the $\mathrm{P}_{\text {value }}$ is $0.448>0.05$. And in total organizational culture has a positive effect on employee performance with a value of 0.060 but not significant because $\mathrm{P}_{\text {value }} 0.800>0.05$. 
Table 4 shows that the variable organizational citizenship behavior on employee performance moderated by work motivation has a coefficient value of 0.114 (positive value) with a $\mathrm{P}_{\text {value }}$ of 0.103 , because $\mathrm{P}_{\text {value }} 0.103>0.05$, it is considered to have no effect even though the coefficient value is positive. While the coefficient value of the independent work motivation variable as an exogenous variable is -0.458 (negative) with a $\mathrm{P}_{\text {value }}$ of 0.094 , which means that work motivation that stands alone as an exogenous variable does not directly affect employee performance and is also not significant, because the $\mathrm{P}_{\text {value }}$ is $0.094>0.05$.

Because the moderating variable (work motivation) has no effect and the work motivation variable as an exogenous variable also has no effect, so in this study the moderation used is the moderating potential category (homologiser moderating). The moderating homologist is a variable that has the potential to be a moderating variable that affects the strength of the relationship between the predictor variable (organizational citizenship behavior (Y1)) and the dependent variable (employee performance). So that it can be said that work motivation can moderate the relationship between organizational citizenship behavior and employee performance.

\section{CONCLUSION}

Based on the data obtained from the analysis, the conclusions of this study are as follows:

1. Leadership style has a positive effect on organizational citizenship behavior of employees at Griya Mahardhika General Hospital Yogyakarta.

2. Organizational culture has a positive effect on organizational citizenship behavior of employees at Griya Mahardhika General Hospital Yogyakarta.

3. Leadership style has a positive effect on employee performance at Griya Mahardhika General Hospital Yogyakarta.

4. Organizational culture has a negative effect on employee performance at Griya Mahardhika General Hospital Yogyakarta.

5. Organizational citizenship behavior has positive effect on employee performance at the Griya Mahardhika General Hospital Yogyakarta.

6. Work motivation can moderate the relationship between organizational citizenship behavior and employee performance at Griya Mahardhika General Hospital Yogyakarta.

7. In the intervening analysis, the total leadership style has a positive effect on employee performance but is not significant.

8. In the intervening analysis, the total organizational culture has a positive effect on employee performance but is not significant.

9. In the analysis of moderating variables, work motivation is included in the category of moderating potential (moderating homologist).

\section{ADVICE}

Based on the results of research, discussion, and conclusions obtained, the suggestions that can be given are as follows:

1. For the General Hospital Griya Mahardhika Yogyakarta

The results of the study on organizational culture variables showed poor results because although organizational culture had a positive effect on organizational citizenship behavior, it had a negative effect on employee performance at Griya Mahardhika General Hospital Yogyarkarta. Which means that although the current organizational culture can 
improve extra-role behavior at work, the organizational culture has not been able to directly improve employee performance.

If extra-role behavior alone can improve employee performance, then if organizational culture can also improve employee performance, it will certainly increase employee productivity at Griya Mahardhika General Hospital, Yogyakarta. For this reason, the leader at the Griya Mahardhika General Hospital Yogyarkarta must make a few changes to the habits or culture that have been carried out so far, especially on indicators of stability and outcome orientation, which are the results with the most disagreeing answers on organizational culture variables.

2. For the next researcher

It is hoped that further researchers will examine more deeply about organizational culture that affects employee performance in order to obtain a more complete picture, so that future research results are expected to be better than this research.

\section{REFERENCE}

Maria, E. (2018). Manajemen Sumber Daya Manusia (1st ed., Vol. 1, Issue November).Yogyakarta: Deepublish. www.deepublish.co.id

Maswar, Jufri, M., \& Mahyani, Z. (2020). "Volume 1, No, 1 Februari 2020." Pengaruh Motivasi Kerja Dan Lingkungan Kerja Terhadap Kinerja Karyawan.

Nataly, D. (2019). Organizational Citizenship Behavior di Sekolah (Alviana (ed.); 1st ed.). Yogyakarta: Samudra Biru.

Saskia, L. A., \& Arief, M. (2020). Ilmu Manajemen. In A. A. N. Rakhmad, D. T. Kurniawan, \& I. Zutiasari (Eds.), Prosiding Seminar Nasional Ilmu Manajemen 2020 Universitas Negeri Malang (p. 108). Universitas Negeri Malang. 